\section{JURNAL PENELITIAN PENDIDIKAN IPA}

http://jurnal.unram.ac.id/index.php/jpp-ipa
e-ISSN : 2407-795X

p-ISSN : 2460-2582

Vol 2, No, 1

Januari 2016

\title{
IMPLEMENTASI MODEL PEMBELAJARAN ADVANCE ORGANIZER MENGGUNAKAN ANIMASI DITINJAU DARI MINAT BELAJAR TERHADAP HASIL BELAJAR KOGNITIF SISWA KELAS VII PADA PELAJARAN IPA DI SMPN 1 BATUKLIANG TAHUN AJARAN 2014/2015.
}

\author{
Erlin Maryani ${ }^{1}$, Muchlis ${ }^{2}$, dan Jamaluddin ${ }^{3}$ \\ Program Studi Magister Pendidikan IPA Program Pascasarjana Universitas Mataram ${ }^{123}$ \\ E-mail: roroerlin@yahoo.in
}

\begin{abstract}
Key Words
Advance organizer, animation, interest, learning achievements.

Abstract

This research was conclude in three main goals. Firstly, the effect of advance organizer implementation using animation on students natural science subject achievement VII Grade Students at SMP. Secondly, the effect of interest of students on learning on the advance organizer implementation using animation on students natural science subject achievement VII Grade Students at SMP. Lastly, the effect of combination between advance organizer implementation using animation and interest on students natural science subject achievement VII Grade Students at SMP. This research was a $2 \times 2$ factorial designs. The result of statistical analyzed using anava two ways showed at 5\% level significant there were significant influence of advance organizer implementatoin using animation on students natural science subject achievement VII Grade Students at SMP (F count 396,6 > F table 6,81), interest of students on learning on the advance organizer implementation using animation on students natural science subject achievement VII Grade Students at SMP (F count 138,4 > F table 6,81), and the combination of between advance organizer implementation using animation and interest on students natural science subject achievement VII Grade Students at SMP (F count 61,95 > F table 6,81). This research was conclude that advance organizer implementation using animation, interest of students on learning on the advance organizer implementation using animation on students natural science subject, and combination of between advance organizer implementation using animation and interest on students natural science subject can highly influence of natural science learning achievements VII Grade Students at SMPN 1 Batukliang.
\end{abstract}

\section{Kata Kunci \\ Model pembelajaran advance organizer, animasi, minat, hasil belajar}

Abstrak
Penelitian ini terdiri dari tiga tujuan. Pertama, mengetahui pengaruh implementasi model
pembelajaran advance organizer menggunakan animasi terhadap peningkatan hasil belajar siswa
pada pelajaran IPA di SMP. Kedua, mengetahui pengaruh minat belajar dengan implementasi
model pembelajaran advance organizer menggunakan animasi terhadap peningkatan hasil belajar
siswa pada pelajaran IPA di SMP. Ketiga, mengetahui interaksi model pembelajaran advance
organizer menggunakan animasi dengan minat belajar terhadap hasil belajar siswa pada pelajaran
IPA di SMP. Penelitian ini menggunakan desain faktorial 2x2. Hasil analisis statistik
menggunakan anava dua jalan pada taraf signifikan $5 \%$ menunjukkan ada pengaruh signifikan
implementasi model pembelajaran advance organizer menggunakan animasi terhadap peningkatan
hasil belajar siswa pada pelajaran IPA di SMP (F hitung $396,6>$ F tabel 6,81), ada pengaruh
signifikan minat belajar dengan implementasi model pembelajaran advance organizer
menggunakan animasi terhadap peningkatan hasil belajar siswa pada pelajaran IPA di SMP (F
hitung 138,4 $>$ F tabel 6,81), dan ada interaksi model pembelajaran advance organizer
menggunakan animasi dengan minat belajar terhadap hasil belajar siswa pada pelajaran IPA di
SMP (F hitung $61,95>$ F tabel 6,81). Implementasi model pembelajaran advance organizer
menggunakan animasi mempengaruhi peningkatan hasil belajar siswa pada pelajaran IPA di SMP,
ada pengaruh minat belajar dengan implementasi model pembelajaran advance organizer
menggunakan animasi terhadap peningkatan hasil belajar siswa pada pelajaran IPA di SMP dan
ada interaksi model pembelajaran advance organizer menggunakan animasi dengan minat belajar
terhadap hasil belajar siswa pada pelajaran IPA di SMP Negeri 1 Batukliang.




\section{PENDAHULUAN}

Peningkatan mutu pendidikan sekolah didapat dari minat dan hasil belajar siswa. Menurut Pangestu (2006) minat belajar penting untuk membantu mencapai peningkatan pemahaman dalam materi pelajaran yang diberikan. Hasil belajar merupakan hal yang dapat dipandang dari dua sisi yaitu sisi siswa dan sisi guru. Dari sisi siswa, hasil belajar merupakan tingkat perkembangan mental baik bila dibandingkan saat sebelum belajar. Tingkat perkembangan mental tersebut terwujud pada jenis-jenis ranah kognitif, afektif, dan psikomotor. Dari sisi guru, hasil belajar merupakan saat terselesaikannya bahan pelajaran (Stifindra, 2011). Selain itu minat juga menentukan sukses atau gagalnya kegiatan seseorang. Sesuatu yang dilakukan dengan penuh minat akan menghasilkan sesuatu yang baik. Makin besar minatnya maka makin besar pula perhatiannya sehingga membesar hasratnya untuk mempelajari IPA. Seseorang yang beminat terhadap IPA maka akan kreatif dalam belajar IPA. Kurangnya minat dan rendahnya hasil belajar siswa diakibatkan karena perencanaan dan implementasi pembelajaran yang dilakukan oleh para guru IPA tampaknya masih dilandasi dengan metode transfer informasi. Hal ini ditunjukkan oleh nilai ujian tengah semester kelas VII belum mencapai nilai rata-rata KKM 75\%. Meskipun telah dicoba beberapa pendekatan, metode ini masih dominan. Cara belajar kurang efektif, minimnya frekwensi dan jumlah waktu belajar, tingkat disiplin diri yang rendah dan media belajar masih kurang menambah kurangnya minat siswa dalam pembelajaran IPA. Siswa tidak dapat melihat hubungan antar materi pelajaran yang telah dipelajari dengan materi berikutnya, ini diperparah dengan sikap guru yang tidak pernah mengingatkan kembali siswa tentang hal tersebut dan terus melanjutkan materi tanpa memperhatikan apakah siswa pada umumnya telah memahami materi yang diberikan. Di samping itu, guru menyampaikan materi masih terpaku hanya pada buku-buku pelajaran dan tidak mencoba untuk mengaitkan materi dengan pengalaman dan pengetahuan yang telah ada pada siswa. Hal tersebut menyebabkan siswa beranggapan bahwa pelajaran IPA tidak menarik dan membosankan. Oleh karna itu, diperlukan model pembellajaran yang dapat menciptakan suasana pembelajaran yang menyenangkan, memungkinkan siswa untuk melakukan refleksi, berpikir serta dapat mengembangkan minat siswa dalam belajar IPA sehingga hasil belajar siswapun meningkat. Oleh karna itu, diperlukan model pembelajaran yang dapat membantu meningkatkan minat dan hasil 
belajar siswa. Model pembelajaran yang menitik beratkan pada cara-cara memperkuat dorongan internal manusia untuk memahami dunia, dengan cara menggali dan mengorganisasi data, merasakan adanya masalah dan mengupayakan jalan pemecahannya serta mengembangkan bahasa untuk mengupayakan jalan pemecahannya serta mengembangkan bahasa untuk mengungkapkannya. Model pembelajaran dengan prinsip di atas adalah model pembelajaran pengelolaan informasi. Salah satu bagian dari model pembelajaran ini adalah model pembelajaran Advance Organizer.

Model pembelajaran advance organizer adalah model pembelajaran yang mengaitkan antara pengetahuan baru dengan pengetahuan yang yang telah ada yang bersumber dari pengalaman siswa sehingga model pembelajaran ini diharapkan mampu memperkuat struktur kognitif siswa sehingga menambah daya ingat siswa terhadap informasi yang bersifat baru. Model pembelajaran advance organizer diartikan sebagai suatu model pembelajaran yang pada prinsipnya siswa dapat menyerap, mencerna, dan mengingat bahan pelajaran dengan baik dalam kegiatannya siswa dapat menjelaskan kembali materi tersebut. Adapun sintaks dari model pembelajaran advance organizer terdiri dari 7 fase yaitu fase 1 menyampaikan tujuan, fase 2 menyajikan informasi, fase 3 mengorganisasi siswa kedalam kelompok-kelompok belajar, fase 4 membimbing kelompok kerja, fase 5 mengembangkan dan menganalisis hasil karya, fase 6 menganalisis dan mengevaluasi hasil belajar dan fase 7 memberikan penghargaan. Penyampaian materi pada sintaks ke 2 model pembelajaran advance organizer adalah dengan menggunakan media animasi dengan program adobe flash.

Animasi merupakan media yang berisi kumpulan gambar yang diolah sedemikian rupa sehingga menghasilkan gerakan yang dilengkapi dengan audio sehingga berkesan hidup serta menyimpan pesan-pesan pembelajaran. Sedangkan jenis animasi yang dimaksud dalam penelitian ini adalah animasi yang dibuat dengan program adobe flash. Materi pelajaran IPA dirangkum dan disajikan dengan media animasi dimaksudkan untuk menarik perhatian siswa pada proses pembelajaran karena pada prinsipnya animasi dapat mewujudkan ilusi bagi pergerakan dengan memaparkan atau menampilkan satu urutan gambar yang berubah sedikit demi sedikit pada kecepatan yang tinggi atau dapat disimpulkan animasi merupakan objek diam yang diproyeksikan menjadikan bergerak sehingga kelihatan hidup. Animasi merupakan gerakan objek 
maupun teks yang diatur sedemikian rupa sehingga kelihatan menarik dan kelihatan lebih hidup (Wikipedia, 2009). Menurut Utami (2007), animasi adalah rangkaian gambar yang membentuk sebuah gerakan. Salah satu keunggulan animasi adalah kemampuannya untuk menjelaskan suatu kejadian secara sistematis dalam tiap waktu perubahan. Hal ini sangat membantu dalam menjelaskan prosedur dalam urutan kejadian. Animasi merupakan salah satu media pembelajaran yang berbasis komputer yang bertujuan untuk memaksimalkan efek visual dan memberikan interaksi berkelanjutan sehingga pemahaman bahan ajar meningkat karena penyajian materi tampak lebih menarik sehingga dapat meningkatkan minat belajar siswa.

Minat adalah kecendrungan jiwa yang tetap untuk memperhatikan dan mengingat beberapa aktivitas atau kegiatan. Minat adalah suatu rasa lebih suka dan rasa keterikatan pada suatu hal atau aktfitas, tanpa ada yang menyuruh. Hal ini diperoleh melalui skor tes minat siswa terhadap IPA. Minat dalam penelitian ini adalah skor yang diperoleh siswa setelah menjawab tes penilaian tentang minat belajar IPA. Minat pada dasarnya adalah penerimaan akan suatu hubungan antara diri sendiri dengan diluar diri. Minat terhadap sesuatu itu kemudian dipelajari dan dapat mempengaruhi belajar selanjutnya akan mempengaruhi penerimaan minat-minat baru sehingga minat terhadap sesuatu merupakan hasil belajar dan cenderung mendukung aktivitas belajar berikutnya, sehingga tingginya minat belajar akan meningkatkan hasil belajar.

Hasil belajar adalah kemampuankemampuan yang dimiliki siswa setelah menerima pengalaman belajarnya. Hasil belajar digunakan oleh guru untuk dijadikan ukuran atau kriteria dalam mencapai suatu tujuan pendidikan. Pengertian hasil belajar yang telah dikemukakan oleh para ahli intinya adalah '"perubahan". Oleh karena itu seseorang yang melakukan aktivitas belajar dan memperoleh perubahan dalam dirinya dengan memperoleh pengalaman baru, maka individu itu dikatakan telah belajar. Orang yang telah berhasil dalam belajar akan menjadi orang yang mandiri dan dapat meningkatkan kesejahteraan hidupnya, serta dapat menentukan arah hidupnya.

\section{METODE PENELITIAN}

Jenis penelitian ini adalah penelitian eksperimen dengan faktorial 4 sel yaitu dengan cara membagi subjek yang diteliti menjadi dua kelompok, yaitu kelompok minat tinggi dan minat rendah pertama dengan perlakuan model pembelajaran advance organizer menggunakan animasi, 
dan kelompok minat tinggi dan minat rendah kedua dengan perlakuan model pembelajaran advance organizer tanpa animasi. Populasi dalam penelitian ini adalah siswa kelas VII SMP Negeri 1 Batukliang. Penentuan sampel dalam penelitian ini yaitu dengan teknik simple random sampling. Hasil pengambilan sampel diperoleh kelas VIIA, VIIC, VIID, dan VIIE. Setelah dilakukan pengambilan sampel secara simple random sampling kemudian dilakukan tes minat pada semua siswa pada kelas terpilih yang terdiri dari kelas VIIA, VIIC, VIID, dan VIIE. Hasil tes kemudian dirangking (diurutkan) berdasarkan kriteria minat dari mulai yang tertinggi sampai yang terendah. Berdasarkan hasil rangking tersebut diperoleh sampel kelas VIIA dan kelas VIID sebagai sampel kelas minat tinggi dan sampel kelas VIIC dan kelas VIIE sebagai sampel kelas minat rendah. Pada masing-masing kelas sampel baik minat tinggi dan minat rendah diberikan perlakuan yang berbeda. Kelas VIIA dan VIIC diberikan perlakuan dengan implementasi model pembelajaran advance organizer menggunakan animasi dan kelas VIID dan VIIE diberikan perlakuan dengan implementasi model pembelajaran advance organizer tanpa animasi.

Pada penelitian ini ada tiga variabel yang menjadi fokus penelitian yaitu variabel bebas dan variabel terikat. Variabel bebas pada penelitian ini adalah model pembelajaran advance organizer menggunakan animasi dan minat belajar IPA siswa kelas VII SMPN 1 Batukliang tahun ajaran 2013/2014 dan variabel terikat pada penelitian ini adalah hasil belajar kognitif IPA siswa kelas VII SMPN 1 Batukliang tahun ajaran 2013/2014. Teknik pengumpulan data pada penelitian ini yaitu hasil belajar kognitif, hasil minat belajar, dan observasi. Data hasil belajar kognitif merupakan data post-test yang dilakukan setelah perlakuan. Data minat belajar merupakan data pre-test yang dilakukan sebelum perlakuan dan post-test yang dilakukan setelah perlakuan. Data pre-test dan post-test diperoleh dengan menggunakan instrumen yang telah diuji validitas dan reliabilitas.

\section{HASIL DAN PEMBAHASAN}

Hasil penelitian berupa hasil tes minat dan hasil belajar kognitif. Hasil tes minat belajar terdiri dari data minat awal (sebelum diberikan perlakuan) dan data minat akhir (setelah diberikan perlakuan). Data minat awal terdiri dari data minat tinggi dan minat rendah. Data minat akhir menunjukkan peningkatan minat setelah dilakukan analisis data.

Skor rata-rata minat belajar siswa sebelum dan setelah diberikan perlakuan dengan implementasi model pembelajaran 
advance organizer dengan animasi dan model pembelajaran advance organizer tanpa animasi dipisahkan menjadi kelompok minat tinggi dan kelompok minat rendah tampak pada Gambar 1

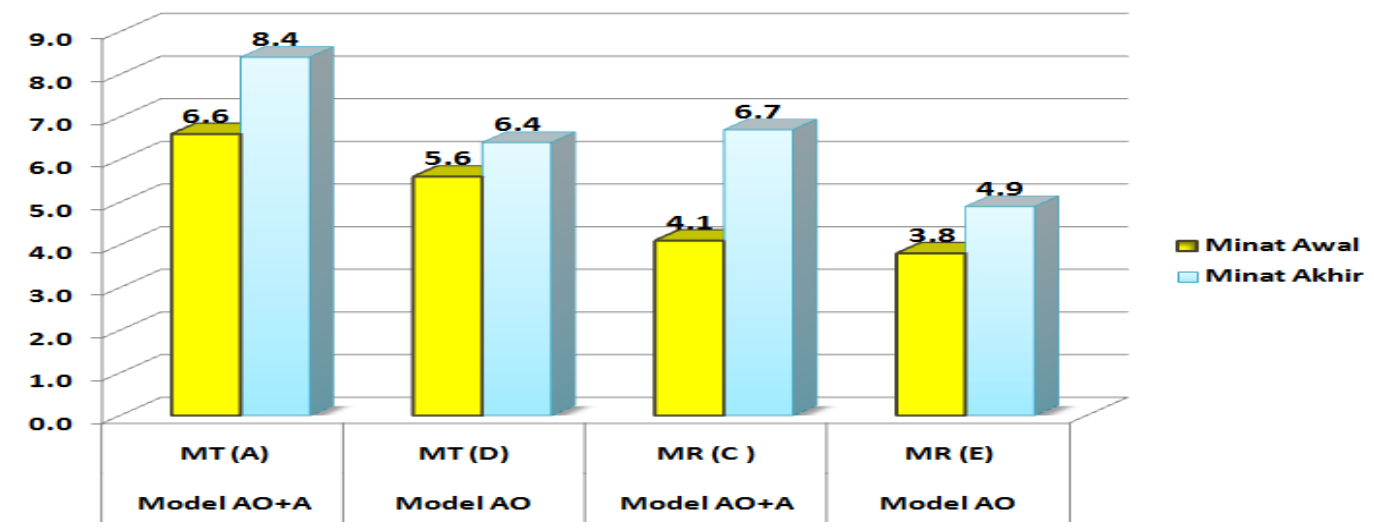

Gambar 1. Peningkatan skor rata-rata minat belajar awal dan minat belajar akhir.

Data hasil penelitian berikutnya adalah hasil belajar kognitif adalah hasil penelitian yang berhubungan dengan pengetahuan atau pengalaman akhir kognitif tentang pelajaran IPA setelah diberikan perlakuan dengan implementasi model pembelajaran advance organizer dengan animasi pada kelompok minat tinggi (A) dan kelompok minat rendah (C) dan implementasi model pembelajaran advance organizer pada kelompok minat tinggi (D) dan minat rendah (E). Data hasil belajar kognitif akhir didapat dari hasil tes akhir. Data hasil belajar setelah diberikan perlakuan dengan implementasi model pembelajaran advance organizer dengan animasi pada kelompok minat tinggi (A) dan kelompok minat rendah (C) dan implementasi model pembelajaran advance organizer pada kelompok minat tinggi (D) dan minat rendah (E) dapat dilihat pada Gambar 2.

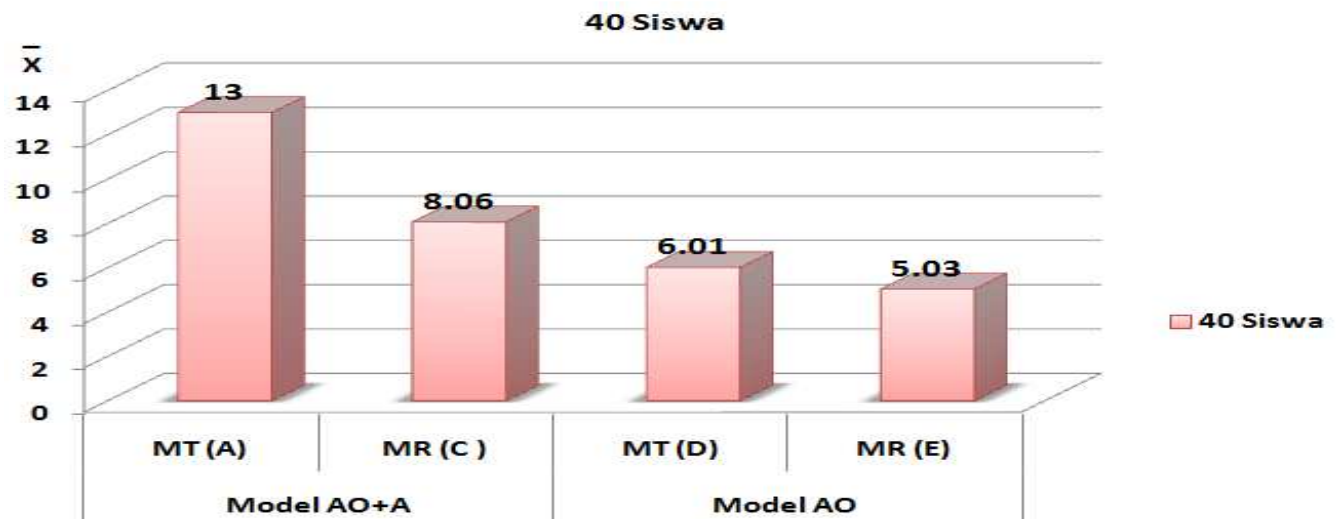

Gambar 2. Nilai rata-rata hasil belajar kognitif siswa minat tinggi dan minat rendah dengan perlakuan model pembelajaran advance organizer dengan animasi dan model pembelajaran advance organizer tanpa animasi. 
Berdasarkan hasil analisis statistik dengan rumus anava dua jalan yang pertama untuk menguji pengaruh implementasi model pembelajaran advance organizer menggunakan animasi dan implementasi model pembelajaran advance organizer tanpa animasi terhadap peningkatan hasil belajar kognitif IPA kelas VII diperoleh hasil yaitu $F_{\text {hitung }}$ 396,6 lebih besar dari $\mathrm{F}_{\text {tabel }}$ 3,91 untuk 1\% dan 6,81 untuk $5 \%$ berarti ada pengaruh implementasi model pembelajaran advance organizer menggunakan animasi terhadap peningkatan hasil belajar kognitif IPA kelas VII. Kedua, pengaruh minat belajar yang menggunakan implementasi model pembelajaran advance organizer menggunakan animasi terhadap peningkatan hasil belajar diperoleh hasil yaitu $F_{\text {hitung }}$ 138,4 lebih besar dari $F_{\text {tabel }}$ 3,91 untuk $1 \%$ dan 6,81 untuk $5 \%$ berarti ada pengaruh minat belajar yang menggunakan implementasi model pembelajaran advance organizer menggunakan animasi terhadap peningkatan hasil belajar. Ketiga, interaksi model pembelajaran advance organizer menggunakan animasi dengan minat belajar terhadap hasil belajar kognitif siswa kelas VII pada pembelajaran IPA di SMPN 1 Batukliang diperoleh hasil yaitu $F_{\text {hitung }} 61,9$ lebih besar dari $F_{\text {tabel }}$ 3,91 untuk $1 \%$ dan 6,81 untuk $5 \%$ berarti ada interaksi model pembelajaran advance organizer menggunakan animasi dengan minat belajar terhadap hasil belajar kognitif siswa kelas VII pada pembelajaran IPA di SMPN 1 Batukliang. Hasil analisis data menggunakan anava dua jalan tampak pada Tabel 1.

Perlakuan yang diberikan kepada keempat kelas baik kelas minat tinggi maupun kelas minat rendah mengalami peningkatan minat dan peningkatan hasil belajar kognitif. Model pembelajaran advance organizer menggunakan animasi dan minat bekerja sama meningkatkan hasil belajar siswa.

Tabel 1. Hasil analisis data menggunakan anava dua jalan

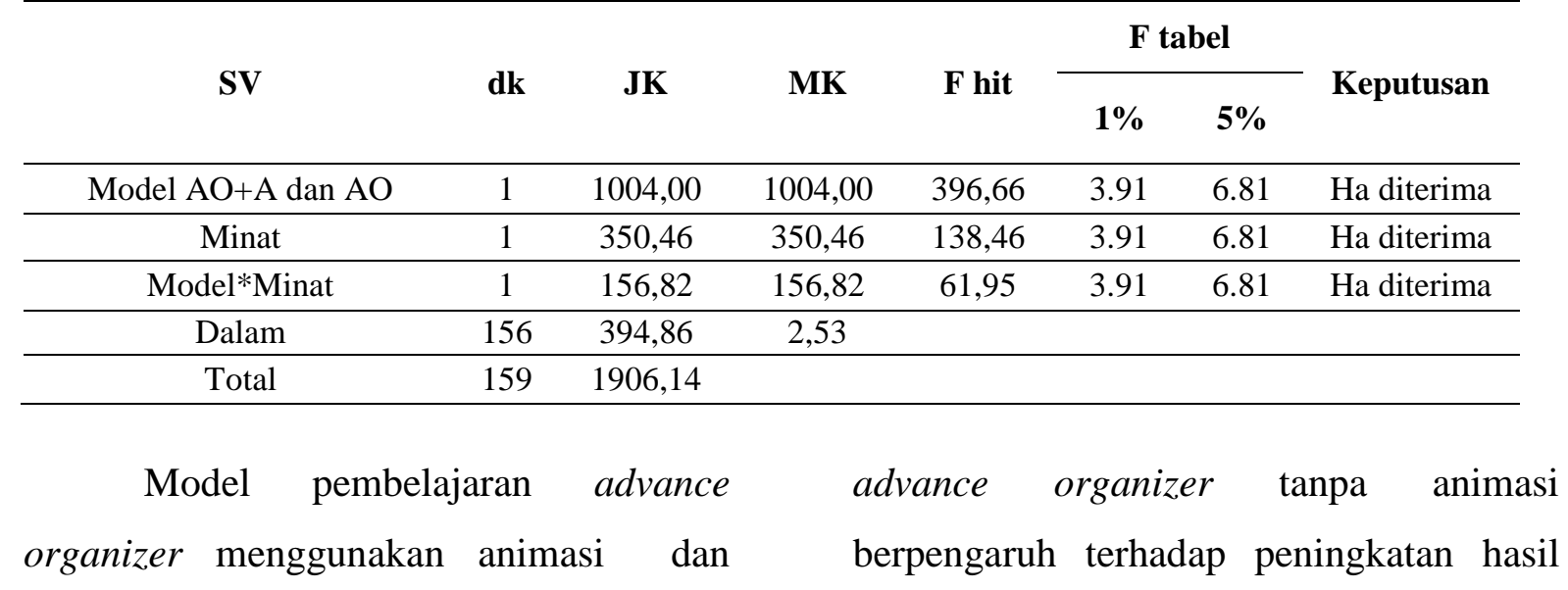


belajar siswa karna mempunyai banyak kelebihan, kelebihan model pembelajaran advance organizer menurut Trianto (2007) yaitu: 1) siswa dapat berinteraksi dengan memecahkan masalah untuk menemukan konsep-konsep yang dikembangkan, 2) dapat membangkitkan perolehan materi akademik dan keterampilan sosial siswa, 3) dapat mendorong siswa untuk mengetahui jawaban pertanyaan yang diberikan (siswa semakin aktif), 4) dapat melatih siswa meningkatkan keterampilan siswa melalui diskusi kelompok, 5) meningkatkan keterampilan berfikir siswa baik secara indvidu maupun kelompok dan 6) menambah kompetensi siswa dalam kelas sehingga siswa dapat berperan aktif dalam proses pembelajaran baik secara individu maupun secara kelompok pada pelajaran IPA. Model pembelajaran advance organizer mempunyai kelebihan dalam memperbaiki proses pembelajaran karena model pembelajaran advance organizer merupakan model pembelajaran yang mengaitkan antara pengetahuan lama dengan pengetahuan baru siswa. Menurut salah satu pernyataan dalam teori Ausubel adalah bahwa faktor yang paling penting yang mempengaruhi pelajaran adalah apa yang diketahui oleh siswa (pengetahuan awal). Dalam implementasinya, model advance organizer ini juga dibantu dengan animasi. Model pembelajaran advance organizer dengan animasi diartikan sebagai suatu model pembelajaran yang pada prinsipnya siswa menyerap, mencerna, dan mengingat pelajaran dengan baik dengan menyertai konsepkonsep yang berupa bentuk, warna, ukuran serta fungsi tertentu (Yeni, 2009). Peningkatan hasil belajar karena implementasi model pembelajaran advance organizer menggunakan animasi disebabkan oleh kegiatan-kegiatan yang dilakukan pada proses pembelajaran, salah satunya adalah mengorganisasi siswa kedalam kelompok-kelompok belajar untuk bekerjasama menyelesaikan masalah dan menuntut siswa persentasi di depan kelas untuk menyampaikan solusi masalah yang diberikan, sehingga penguasaan siswa terhadap materi meningkat. Hal ini didukung oleh peneitian yang dilakukan oleh Muhammad dan Nur (2004) model pembelajaran advance organizer merupakan suatu pendekatan konstruktivis didasarkan pada prinsip mengorganisasikan siswa kepada materi sebelum dibaca atau presentasi kelas, yang digunakan untuk memperbaiki kinerja siswa yang memiliki pemahaman rendah sehingga dapat meningkatkan hasil belajar siswa. Maka implementasi model pembelajaran advance organizer menggunakan animasi berpengaruh terhadap peningkatan hasil belajar kognitif siswa kelas VII di SMPN 1 Batukliang. 
Hasil analisis kedua menunjukkan bahwa ada pengaruh minat belajar dengan implementasi model pembelajaran advance organizer menggunakan animasi terhadap peningkatan hasil belajar kognitif siswa. Hal ini disebabkan karena minat merupakan suatu rasa lebih suka dan rasa keterikatan pada suatu hal atau aktfitas, tanpa ada yang menyuruh. Beberapa ahli psikologi memberikan pendapat mengenai definisi minat yang pada dasarnya mempunyai makna yang sama, namun memberikan penekanan yang berbeda. Menurut Whitterington (1985), minat adalah kesadaran seseoang, bahwa suatu objek, seseorang, suatu soal atau suatu situasi mengandung sangkut paut dengan dirinya. Guilford (1969) menyatakan bahwa minat merupakan suatu kecenderungan seseorang untuk berprilaku atas ketertarikannya dengan jenis-jenis kegiatan tertentu, kemudian dilengkapi oleh Crow and Crow (1973), bahwa minat merupakan kekuatan yang mendorong individu dalam memberi perhatian terhadap suatu kegiatan tertentu, dengan kata lain minat menjadi sebab partisipasi dalam kegiatan. Ini berarti minat bisa timbul bila ada sesuatu yang merangsang pada diri seseorang kemudian mendapat respons. Sehingga dengan menumbuhkan minat belajar sains banyak cara atau metode yang digunakan guru maupun peneliti untuk menumbuhkannya. Salah satunya oleh Nugraheni (2007) yang meneliti peningkatan minat sains dengan menggunakan pendekatan kontekstual. Dalam penelitian tersebut diperoleh hasil minat belajar sains dari skor 64,83 (berminat) menjadi skor 70,67 (sangat berminat). Selain itu penelitian lain yang bertujuan menumbuhkan minat yang dilakukan dengan berbagai metode dan media, seperti dengan dengan permainan (Yuniar, 2007), eksperimen dan media visual (Dessy, 2009), alat peraga (Sugiharti, 1995), dan menggali pengetahuan awal siswa serta pemberian tugas rumah (Amiruddin, 2000) terbukti dapat meningkatkan minat siswa terhadap apa yang diajarkan oleh guru. Dengan demikian sangatlah penting bagi seorang guru untuk mengetahui karakteristik suatu mata pelajaran agar dapat menentukan metode yang tepat sehingga apa yang diajarkan dapat mencapai tujuan yang diharapkan, misalnya peningkatan minat belajar IPA. Minat yang merupakan sebuah motivasi intrinsik sebagai kekuatan pembelajaran yang menjadi daya penggerak seseorang dalam melakukan aktivitas dengan penuh ketekunan dan cenderung menetap, dimana aktivitas tersebut merupakan proses pengalaman belajar yang dilakukan dengan penuh kesadaran dan mendatangkan perasaan senang, suka dan gembira. Memiliki motivasi intrinsik dan belajar dengan 
perasaan senang karena penyampaian materi pelajaran dengan model pembelajaran advance organizer menggunakan animasi yang menarik perhatian dapat meningkatkan minat belajar IPA karena minat adalah penentu sukses atau gagalnya seseorang. Sesuatu yang dilakukan dengan penuh minat akan menghasilkan sesuatu yang baik. Makin besar minatnya maka akan semakin besar perhatiannya sehingga membesar hasratnya untuk mempelajari IPA. Seseorang yang berminat terhadap IPA akan kreatif belajar IPA. Semakin kreatif belajar IPA akan meningkatkan daya ingat dan pemahaman terhadap materi pelajaran IPA. Daya ingat dan pemahaman yang tinggi terhadap materi pelajaran IPA akan meningkatkan hasil belajar IPA. Maka, ada pengaruh minat belajar dengan implementasi model pembelajaran advance organizer menggunakan animasi terhadap peningkatan hasil belajar kognitif siswa kelas VII pada pelajaran IPA di SMP Negeri Batukliang Kabupaten Lombok Tengah.

Hasil analisis ketiga menunjukkan adanya interaksi model pembelajaran advance organizer menggunakan animasi dengan minat belajar terhadap peningkatan hasil belajar kognitif siswa. Implementasi model pembelajaran advance organizer menggunakan animasi mempengaruhi peningkatan hasil belajar kognitif siswa yang minat belajarnya tinggi dan minat belajarnya rendah. Demikian juga dengan peningkatan minat belajar dengan implementasi model pembelajaran advance organizer menggunakan animasi mempengaruhi peningkatan hasil belajar kognitif siswa. Hal ini disebabkan karena minat dengan model pembelajaran advance organizer menggunakan animasi bekerjasama meningkatkan hasil belajar siswa. Fakta ini diperkuat oleh Hudson dan Keraro (2009) pada penelitiannya tentang penerapan model pembelajaran advance organizer yang sangat efektif membangun perhatian siswa sehingga mampu meningkatkan minat dan hasil siswa. Maka, ada interaksi model pembelajaran advance organizer menggunakan animasi dengan minat belajar terhadap peningkatan hasil belajar kognitif siswa kelas VII pada pelajaran IPA di SMP Negeri Batukliang Kabupaten Lombok Tengah.

\section{KESIMPULAN}

Berdasarkan hasil penelitian dan pembahasan yang telah dilakukan oleh peneliti, dapat disimpulkan bahwa ada pengaruh implementasi model pembelajaran advance organizer menggunakan animasi terhadap peningkatan hasil belajar kognitif siswa kelas VII pada pembelajaran IPA di SMP Negeri Batukliang Kabupaten Lombok Tengah, ada pengaruh minat belajar 
dengan model pembelajaran advance organizer menggunakan animasi terhadap peningkatan hasil belajar kognitif siswa kelas VII pada pembelajaran IPA di SMP Negeri Batukliang Kabupaten Lombok Tengah, dan ada interaksi model pembelajaran advance organizer menggunakan animasi dengan minat belajar terhadap peningkatan hasil belajar kognitif siswa kelas VII pada pembelajaran IPA di SMP Negeri Batukliang Kabupaten Lombok Tengah.

\section{DAFTAR PUSTAKA}

Hudson and Keraro. 2009. Using Advance Organizer to Enhance Students' Motivation in Learning Biology. Eurasia Journal of Mathematics, Science \& Tecnology Education: 413-420.

Pangestu. 2006. Minat Belajar Untuk Meningkatkan Prestasi Belajar Siswa. Jurnal Pendidikan. 30-47.

Stifindra. 2011. Hasil Belajar. (Online): http://buku.infogue.com/hasil_belajar _pengertian_dan_definisi_, Diakses tanggal 20 Juni 2011.

Wikipedia. 2009. Animasi. (Online): http://www.scribd.com.com/doc/539 26104/16/Media-animasi, Diakses tanggal 2 Juli 2011.

Utami, D. 2007. Animasi Dalam Pembelajaran. Yogyakarta: Kanisius.

Yeni, Sanjaya. 2009. Model-model Pembelajaran. Jakarta: Prestasi Pustaka Publisher.
Muhammad dan Nur. 2004. Metodologi Penelitian Jakarta: Raja Grafinda Persada.

Trianto. 2010. Media Pembelajaran. Jakarta: Prestasi Pustaka Publisher.

Nugraheni, Diah. 2007. Meningkatkan Minat Belajar Sains (IPA) dengan Menggunakan Pendekatan Kontekstual pada Pokok Bahasan Cahaya Siwa Kelas V Semester II Sekolah Dasar Kedungmundu 01 Semarang Tahun Pelajaran 2006/2007. Skripsi S1. Universitas Negeri Semarang.

Whitterington. 1985. Psikologi Pendidikan. Terj. M. Buchori. Jakarta: Angkasa.

Yuniar, Adi. 2007. Minat Siswa Terhadap Olah Raga Bola Voli di SMPN 1 Larangan Kabupaten Brebes Tahun Ajaran 2006/2007. Skripsi S1. Universitas Negeri Semarang.

Dessy, G.A. 2009. Peningkatan Minat dan Hasil Belajar Sains Melalui Pelaksanaan Metode Eksperimen Dengan Bantuan Media CD Pembelajaran Pada Materi Gaya Kelas V Semester I SD Negeri 2 Skaran Gunung Pati Tahun Pelajaran 2008/2009. Skripsi S1. Universitas Negeri Semarang.

Sugiharti, Gulmah. 1995. Cara Guru Membangkitkan Minat Siswa Belajar Kimia Pada Pokok Bahasan Sistem Periodik Unsur: studi deskriptif terhadap cara mngajar guru kimia di SMA Negeri sekotamadya Binjai. Tesis S2. Universitas Pendidikan Indonesia.

Guilford, J.P. 1969. Personality. New York: Mc Graw Hill Book Company.

Amiruddin. 2000. Teknik Pembangkitan Minat Siswa Dalam Belajar Fisika: 
Jurnal Penelitian Pendidikan IPA (JPPIPA), Januari 2016

Studi Deskriptif Tentang Teknik Mengajar Guru Fisika Klas 1 MAN Bandung. Tesis S2. Universitas Pendidikan Indonesia.
Crow and Crow, Lester D. 1973. Educational Psycology. New York: American Book Company. 